\title{
Trading Intensity and Real Estate Performance
}

\author{
Dirk Brounen • Piet Eichholtz • David C. Ling
}

Published online: 24 August 2007

(C) Springer Science + Business Media, LLC 2007

\begin{abstract}
This paper investigates whether it is possible to create value through the active management of direct property portfolios. Using data from the USA, the UK and Australia, we examine whether trading intensity and portfolio growth explain the risk and return characteristics of listed property companies. The results suggest that beating the market by pursuing tactical asset selection and investment timing strategies is difficult even when acquiring and disposing of properties in illiquid private property markets. When the property type in which the firm specializes is included as a control variable in the regressions, none of the portfolio management intensity indicators developed in this paper is significantly associated with abnormal performance or systematic risk.
\end{abstract}

Keywords Trading intensity $\cdot$ Turnover $\cdot$ Expansion

\section{Introduction}

Portfolio returns in excess of the risk free rate can result from: (1) the incremental risk imbedded in the portfolio and (2) from the incremental value added arising from the skills (or luck) of the portfolio manager, not related to risk. Four investment tasks or activities have the potential to create value for real estate investors. The first is the design and construction of the investor's portfolio. Diversification is a powerful tool that has the potential to increase expected returns without increasing the riskiness of the overall

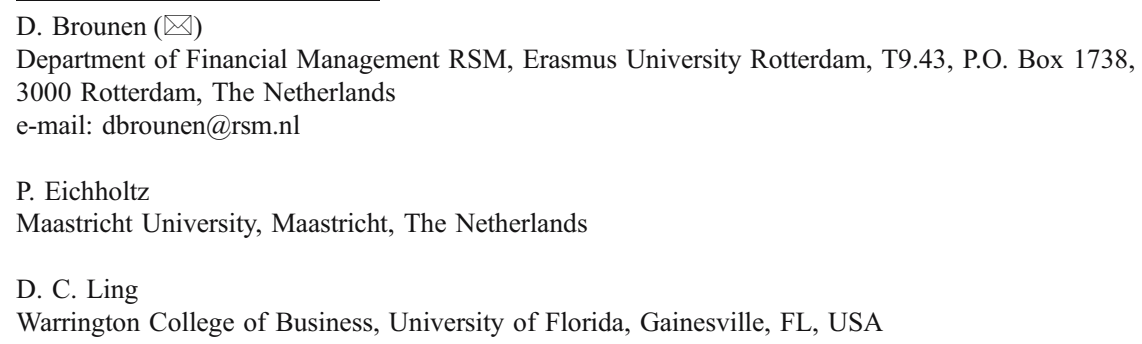


portfolio. As has been well documented in both the academic and practitioner literature, managers can provide significant value-added by helping undiversified investors get on, or near, the efficient frontier.

A second potential source of manager value added is the ability to pick property type and/or geographic "winners and losers" and to time the market. Clearly, if a manager can accurately predict, for example, the optimal time to sell office buildings in London and buy retail properties in Amsterdam, risk-adjusted portfolio returns can be significantly enhanced.

A third task which can enhance risk-adjusted returns is "deal execution." Many real estate investors face a classic Akerlof (1970) asymmetric information (i.e. "lemons") problem; that is, potential buyers often know less about the income producing ability of a property than the seller. This is especially true for buyers not familiar with the local market in which the property is located. A manager's knowledge of the immediate market area and his expertise in due diligence, underwriting, and negotiations can help ensure the investor does not overpay for properties at acquisition. Making good acquisition decisions is important because, by their nature, they cannot be undone easily or costlessly.

A fourth potential source of manager value added is the efficient provision of ongoing asset and property management services. The ownership of commercial real estate puts investors in the business of providing services to users of the space and the provision of these rental services is management intensive. Moreover, the majority of the expected holding period return on acquisitions of existing commercial properties comes from periodic net rental income, not from expected appreciation in the value of the property. As a result, commercial real estate returns are determined in no small part by how well the ongoing management function is performed.

The important roles played by portfolio diversification and ongoing management in protecting and enhancing risk-adjusted commercial real estate returns are widely acknowledged. Moreover, in recent years a stream of papers have provided theoretical and empirical support for the importance of geographical and property type focus (see, for example, Capozza and Seguin 1999, Eichholtz et al. 2001, and Boer et al. 2005). What is much less clear from the literature, however, is the extent to which active portfolio managers can add, or destroy, value by pursuing tactical, i.e. "opportunistic," asset selection and investment timing strategies. This paper examines the question: Do real estate portfolio managers who pursue such opportunistic investment strategies add value for investors?

Measuring the value added arising from tactical market timing strategies is more complicated for managers that invest in private real estate markets because truly passive investment strategies against which an active strategy could be benchmarked are not possible. This is because index products akin to those that mimic the return on the S\&P 500 and other stock market indices have not been available to investors in private commercial real estate markets. ${ }^{1}$ The lack of tradable passive benchmarks has required

\footnotetext{
${ }^{1}$ In 2005, the National Council of Real Estate Investment Fiduciaries (NCREIF) granted Credit Suisse First Boston (CSFB) a 2 year exclusive contract to create a market in derivative securities based on the NCREIF Property Index (NPI). In February of 2006, Credit Suisse announced it had successfully completed the first two standardized property derivative transactions tied to the NPI. If successful, the development of a derivatives market could have a profound effect on the liquidity and transparency of commercial real estate markets.
} 
both public and private real estate investment entities to purchase illiquid, whole assets in private markets that require significant amounts of managerial effort to acquire, maintain, and dispose.

We define active real estate managers as those who pursue tactical market timing and asset selection strategies for their private property portfolios. Such opportunistic investment strategies should, on average, produce more acquisition and disposition activity than more passive buy-and-hold strategies. More specifically, we examine the effects of portfolio management "intensity" on the risk and return characteristics of publicly trade real estate companies that purchase their assets in private markets. Although a company's stock price performance is likely to be more volatile than the performance of its underlying real estate portfolio, this approach provides direct evidence of the shareholder wealth created by active real estate portfolio strategies.

The research employs a sample of publicly traded firms that spans 8 years (1996-2003) and includes the three largest public real estate markets in the world: the USA, the UK, and Australia. We measure firm level performance in several ways. First, we calculate excess (i.e., risk-adjusted) stock returns and market betas using both single factor and multifactor asset pricing models. The excess returns (or "alphas") and market betas from these models are then regressed on several indicators of portfolio management intensity, including the frequency of property acquisitions and dispositions, the firm's portfolio turnover rate, and the extent to which the firm has expanded the size of its real estate portfolio, as well as a number of control variables. We also estimate the relation between our management intensity indicators and two measures of firm-level operating performance: return on assets and return on equity.

When the primary property type in which the firm invests is included as a control variable in the second stage regressions, none of the portfolio management intensity indicators developed in this paper is significantly associated with excess stock returns, systematic risk, or enhanced operating performance. Thus, our empirical results indicate that generating excess returns using an active trading strategy is difficult for publicly traded real estate firms, even though they are acquiring and disposing of assets in illiquid private property markets.

The paper proceeds as follows. In the next section, we briefly review the relevant literature on management intensity and performance. "Research Methodology" describes our research methodology, while "Data Sources and Summary Statistics" contains a description of the data as well as summary statistics for our measures of management intensity and performance. Our regression results are presented and discussed in "Risk-Adjusted Stock Returns and Operating Performance," while our findings and their implications are discussed in a concluding section.

\section{The Related Literature}

The traditional formulation of the efficient market hypothesis (EMH) precludes the existence of manager value added or "alpha" (Jensen 1968a, Fama 1970). In the absence of manager alpha, active management (portfolio churning), with its attendant transaction costs, destroys portfolio values. In fact, investors who purchase actively managed stock mutual funds are, effectively, buying into the fund manager's 
attempt to obtain information on individual stock selections that will generate excess returns. If superior performance can't be obtained through such information, then passive management, or index-tracking, is a more efficient way to manage the assets of the fund (Engstrom 2003).

Numerous studies have focused on the ability of actively managed mutual funds to outperform funds that passively track a tradable benchmark index. Although the proper technique for risk-adjusting returns when calculating manager alphas is a topic of ongoing debate, recent studies of the performance of stock mutual funds conclude that fund managers are not able to time the market (Chen et al. 2005), that the average mutual fund alpha is negative once adjustments for fund style are made (Carhart 1997; Wermers 2000), and that funds that trade more frequently have, at best, marginally better stock picking skills than funds that trade less often (Chen et al. 2001). However, some recent evidence suggests that a minority of active mutual fund managers do pick stocks well enough to cover their trading costs (Wermers 2000; Baker et al. 2004; Kosowski et al. 2005), although Wermers (2003) concludes that this outperformance is reflected in only a minority of funds that take relatively large volatility bets.

What about the ability of managers who buy and sell public real estate firms to generate positive alphas for their investors? Given the increased transaction costs associated with active real estate investment strategies, their use implies that the portfolio manager believes returns on the underlying assets are, at least, partially predictable. And, in fact, some recent research has produced limited evidence that returns on publicly traded real estate securities are partially predictable (see, for example, Liu and Mei 1992; Mei and Liu 1994; Cooper et al. 1995; Li and Wang 1995; Karolyi and Sanders 1998; Ling et al. 2000; Brooks and Tsolacos 2003). However, the preponderance of evidence that currently exists suggest that superior return performance using a market timing strategy to buy and sell public real estate firms is not possible once transaction costs are incorporated into the analysis. A notable recent exception is a paper by Kallberg et al. (2000) who analyze the performance of REIT mutual funds. They find positive average alphas net of trading costs, which are positively related to portfolio size and turnover.

Despite limited evidence of return predictability and manager value in the acquisition of publicly traded real estate securities, many analysts and investors have concluded that skilful portfolio managers can add value (on a risk-adjusted basis) through asset selection and investment timing strategies when acquiring and disposing of properties in private real estate markets. ${ }^{2}$ This conclusion is based on the widely held view among practitioners that private commercial real estate markets exhibit persistent inefficiencies that can be exploited by superior investment managers. The purported inefficiencies are thought to arise from an absence of centralized price information or transactions, infrequent trading, a lack of transparency in the transactions that do occur, and the heterogeneity and indivisibility of commercial real estate assets. If private real estate markets are less competitive than markets for public securities, the potential payoff from market timing and other tactical investment strategies is expected to be greater.

\footnotetext{
${ }^{2}$ See, for example, Han (1996), Hall (2004), Stoesser and Hess (2000), and Smith (2005).

Springer
} 
The recent proliferation of real estate investment funds and management strategies is evidence that many investors believe real estate portfolio managers can indeed add value by acquiring properties directly in the private market. These funds and strategies are known by descriptive names such as "enhanced core," "value added," or "opportunistic," depending loosely on the magnitude of the excess returns targeted by the fund (Stoesser and Hess 2000; Conner and Liang 2003). The increased returns expected to be produced by these strategies are typically thought to arise from the manager's ability to successfully "target" geographical markets and/or property types, to time individual property acquisitions and dispositions, and to employ financial leverage in a wealth increasing fashion (Ling 2005).

Despite the apparent widespread belief among practitioners that private real estate markets are inefficient and, therefore, predictable, the limited empirical evidence available for examination does not support this belief. For example, McAllister et al. (2005) examine the ability of 18-31 real estate experts to forecast total returns on an aggregate index of privately held commercial properties in the UK. The index is produced by the Investment Property Databank (IPD). ${ }^{3}$ The annual mean absolute forecast error for the 6-year (1999-2004) sample period was 4.8\%. As an example, at the beginning of 2004 the forecast consensus among the experts was that the IPD Index would produce a total return of $7 \%$. The actual 2004 total return was $17 \%{ }^{4}$ Marcato and Key (2005) do uncover evidence of return momentum (i.e., predictability) in monthly IPD subindices. However, the authors conclude that the potential gains from employing a momentum trading strategy are likely offset by increased trading costs. ${ }^{5}$ They also acknowledge that the relative lack of liquidity in private real estate markets would make it difficult to implement an investment strategy based on short-term return momentum. Finally, in an analysis of institutional investors and managers, Ling (2005) finds no evidence that the consensus survey forecasts of experts are predictive of subsequent total return performance-either by property type or by metropolitan area.

Although these results suggest that making accurate return predictions is difficult, they provide only indirect evidence on the ability of managers to generate outperformance in the private real estate markets. One could argue that expert portfolio managers would not willingly share their valuable knowledge about future market developments with survey researchers. On the contrary, such managers would attempt to use their knowledge and expertise to enhance the performance of their own portfolios. Moreover, the superior (or inferior) performance of individual asset managers is averaged out when their performance is aggregated into a NCREIF or IPD index.

\footnotetext{
${ }^{3}$ For more information on IPD, go to http://www.ipdindex.co.uk.

${ }^{4}$ It is worth noting that, similar to the NCREIF Index in the U.S., the U.K. IPD Index suffers from temporal lag bias (i.e., "smoothing"). This serial correlation should, in fact, make the total return on the IPD index easier to predict. The analysis by McAllister et al. (2005) also does not consider the magnitude of the transaction costs that would be associated with rebalancing a portfolio based on the periodic return predictions of the experts.

${ }^{5}$ Moreover, Marcato and Key (2005) do not unsmooth the monthly IPD indices which, as they acknowledge, suffer from a high degree of return smoothing and, therefore, predictability.
} 
To obtain a more direct test of manager value added, we examine the firmlevel performance of public companies that invest in the private markets. Restricting our analysis to the private market activities of public companies has several advantages. First, total return data based on continuously observed transaction prices are available to measure excess returns and systematic risk. ${ }^{6}$ Second, the public nature of the firms in our sample provides access to audited financial statements that contains the dates and transaction prices of all property acquisitions and dispositions.

\section{Research Methodology}

To classify public real estate firms along the active-passive spectrum with respect to their activities in private markets, we construct and analyze a number of management intensity indicators. Before presenting these measures, we note that they are constructed to measure portfolio activity, not management skills. Abnormal performance may result from skill or luck and it is difficult to distinguish the two empirically. However, investors in listed property companies are able to distinguish active portfolio managers from passive ones, as we do in this paper. Our empirical approach is consistent with analyzes of management intensity and performance that have appeared in the mutual fund performance literature. ${ }^{7}$

\section{Trading Activity}

Our trading activity indicator measures the number of properties purchased in a given year, plus the number of properties sold, relative to the average number of properties in the portfolio during the year. More specifically, the trading activity indicator for firm $i$ over a $n$ year sample period is defined as:

$$
\operatorname{TRADING}_{i}=\sum_{t=1}^{n}\left(\left(\frac{2 B u y_{i t}}{\left(X_{i(t-1)}+X_{i t}\right)}\right)+\left(\frac{2 \text { Sell }_{i t}}{\left(X_{i(t-1)}+X_{i t}\right)}\right)\right) / n,
$$

where Buy ${ }_{i t}$ and Sell $_{i t}$ refer, respectively, to the number of properties bought and sold by firm $i$ in year $t$, and $X_{i t}$ is the number of properties held by firm $i$ at the end of year $t$. The first term in Eq. 1 captures acquisition activity in year $t$ relative to the average number of properties in the portfolio in year $t$, while the second term captures the corresponding sales activity. TRADING $i$ is the average of the index

\footnotetext{
${ }^{6}$ Returns on private firms/funds that invest in private commercial real estate markets are derived from (usually quarterly) estimates of the changes in underlying property values. These returns are therefore susceptible to appraisal smoothing.

${ }^{7}$ See for example Wermers (2000), Baker et al. (2004), and Kosowski et al. (2005).

를 Springer
} 
value over a designated $n$-year period. We posit that a high level of asset trading is a proxy for an active management strategy. ${ }^{8}$

\section{Turnover Rate}

Our second measure of management intensity is the portfolio turnover rate. According to Sharpe et al. (1999), a portfolio's turnover rate is equal to the dollar value of sales during time period $t$ divided by the average dollar value of the portfolio or firm in period $t$. Thus, the average portfolio turnover rate for firm $i$ over a $n$-year sample is defined as:

$$
\text { TURNOVER }_{i}=\sum_{t=1}^{n}\left(\frac{\text { 2Sales }_{i t}}{\left(R E_{i(t-1)}+R E_{i t}\right)}\right) / n,
$$

where $\operatorname{Sales}_{i t}$ is the value of property sales (measured in the local currency) in year $t$ and $\mathrm{RE}_{i t}$ is the total value of firm $i$ 's assets at the end of year $t$. The difference between TRADING TRA TURNOVER $_{i}$ is that the former is based on the number of properties acquired or sold whereas $\mathrm{TURNOVER}_{i}$ is based on the dollar value of dispositions.

\section{Portfolio Expansion}

To capture the extent to which a firm has grown the number of properties in its portfolio over a designated period, we also construct the following portfolio expansion measure:

$$
\operatorname{EXPANSION}_{i}=\sum_{1}^{n}\left(\frac{X_{i t}}{X_{i(t-1)}}\right) / n,
$$

where $X_{i t}$ refers to the number of properties owned by firm $i$ at the end of year $t$. EXPANSION $_{i}$ captures the average annual increase in the number of properties owned by firm $i$ over a $n$-year period.

\section{Measuring and Explaining Abnormal Performance}

Jensen's (1968b) single-factor model of excess returns posits only one potential source of systematic risk in the economy-i.e., exposure to fluctuations in the return on the market portfolio. ${ }^{9}$ However, several recent studies have documented the existence of multiple systematic risk factors in stock, bond, and commercial real

\footnotetext{
${ }^{8}$ We are careful to control for firm-level mergers and acquisitions. More specifically, if a firm grows its portfolio in a given year through an acquisition of another entity, the acquisition year is excluded from the sample. Activity in the subsequent year is measured relative to a portfolio that includes the properties acquired in the prior year. Although we believe we are correctly counting the number of acquisitions and dispositions in cases where mergers and acquisitions are involved, REIT mergers often involve the transfer of human capital as well as real assets. The perceived value of the acquired human capital may affect stock prices and thereby create noise in our estimated regressions. We thank one of the referees for making this observation.

${ }^{9}$ One can view the market portfolio as a portmanteau variable proxying for a set of latent risk factors.
} 
estate markets. ${ }^{10}$ Thus, Jensen's single-factor model may be misspecified due to the existence of omitted systematic risk variables. We therefore also implement a multifactor model of excess real estate returns using the Fama-French factors (i.e., SMB and HML), which have been shown in a large number of studies to help explain the cross section of stock returns, in addition to the standard market risk factor $(M K T){ }^{11}$ More specifically, we first estimate the following multifactor regression for each firm in our sample using monthly data:

$$
\left(R_{i t}-R_{f t}\right)=\alpha_{i}+\beta_{i, M K T}\left(R_{M K T t}-R_{f t}\right)+\beta_{i, S M B}\left(S M B_{t}\right)+\beta i_{, H M L}\left(H M L_{t}\right)+\varepsilon_{i t}
$$

where:

\begin{tabular}{|c|c|}
\hline$R_{i t}$ & $\begin{array}{l}\text { he total return of firm } i \text { in month } t \text {, } \\
\text { he risk free rate in month } t \text {. }\end{array}$ \\
\hline$\alpha_{i}$ & $\begin{array}{l}\text { a constant (i.e., "alpha") that captures average monthly excess return } \\
\text { performance over the estimation period., }\end{array}$ \\
\hline$\beta_{i, \mathrm{MKT}}$ & $\begin{array}{l}\text { tivity of firm } i \text { 's excess returns to excess returns on the } \\
\text { ortfolio, }\end{array}$ \\
\hline$R_{\mathrm{MKT}, t}-R_{f t}$ & $\begin{array}{l}\text { period } t \text { excess return associated with an investment in the market } \\
\text { rtfolio, }\end{array}$ \\
\hline & sensitivity of firm $i$ 's excess returns to the SMB risk factor, \\
\hline $\mathrm{SMB}_{t}$ & $\begin{array}{l}\text { difference between the return on a portfolio of small cap stocks } \\
\text { the return on a portfolio of large stocks during month } t \text {, }\end{array}$ \\
\hline & e sensitivity of firm $i$ 's excess returns to the $H M L$ risk factor, \\
\hline HML $t$ & $\begin{array}{l}\text { difference between the return on a portfolio of high book-to- } \\
\text { arket-value stocks and the return on a portfolio of low book-to- } \\
\text { arket-value stocks during month } t \text {, and }\end{array}$ \\
\hline & \\
\hline
\end{tabular}

As is discussed more fully below, we estimate Eq. 4 for two separate 48 month sample periods. We control for cross-national variation in excess returns by running separate regressions for each of our three counties.

In our second stage cross-sectional regressions, we examine the ability of our measures of management intensity and a set of control variables to explain the variation across firms in the alphas and market betas $\left(\beta_{i, M K T}\right)$ obtained from estimating Eq. 4. More specifically, for each four-year subsample in our 8-year study period, we estimate the following set of cross-sectional regressions:

$$
\begin{gathered}
\alpha_{i}=\lambda_{0}+\lambda_{1}\left(C V 1_{i}\right)+\lambda_{2}\left(C V 2_{i}\right)+\ldots+\lambda_{n}\left(C V_{n i}\right)+\varepsilon_{i t} \\
\alpha_{i}=\lambda_{0}+\lambda_{1}\left(C V 1_{i}\right)+\lambda_{2}\left(C V 2_{i}\right)+\ldots+\lambda_{n}\left(C V_{n i}\right)+\lambda_{a}\left(\operatorname{TRADING}_{i}\right)+\varepsilon_{i t}
\end{gathered}
$$

\footnotetext{
${ }^{10}$ See, for example, Chen et al. (1986), Ferson and Harvey (1991), and Ling and Naranjo (1997).

${ }^{11}$ Fama and French (1996) show that the cross-sectional variation in expected returns associated with most equity investments can be explained within their three factor model. They argue that $S M B$ and $H M L$ are state variables in an intertemporal asset pricing model, although rational asset pricing theories do not clearly show how $S M B$ and $H M L$ are related to the underlying undiversifiable macroeconomic risks.
} 


$$
\begin{aligned}
& \alpha_{i}=\lambda_{0}+\lambda_{1}\left(C V 1_{i}\right)+\lambda_{2}\left(C V 2_{i}\right)+\ldots+\lambda_{n}\left(C V_{n i}\right)+\lambda_{a}\left(\text { TURNOVER }_{i}\right)+\varepsilon_{i t} \\
& \alpha_{i}=\lambda_{0}+\lambda_{1}\left(C V 1_{i}\right)+\lambda_{2}\left(C V 2_{i}\right)+\ldots+\lambda_{n}\left(C V_{n i}\right)+\lambda_{a}\left(\text { EXPANSION }_{i}\right)+\varepsilon_{i t}
\end{aligned}
$$

where $\alpha_{i}$ is the firm-specific alpha obtained from the first stage regressions and $\mathrm{CV}_{1}$ through $\mathrm{CV}_{n}$ are control variables that have been shown to be important in explaining the cross-section of stock returns. These include the firm's stock market capitalization, leverage rate, dividend yield, earnings per share, price earnings ratio, and price-to-book ratio, and $\varepsilon_{i t}$ is a standard error term. The primary coefficient of interest is $\lambda_{a}$, the estimated coefficient for our trading intensity variables. Because of the potential for correlation among our management intensity indicators, we enter each separately in our second stage regressions. A corresponding set of second stage regressions are run for each country using the beta estimates $\left(\beta_{i, \mathrm{MKT}}\right)$ from Eq. 4 as the dependent variable. Finally, we also quantify the effect of portfolio management intensity on operating performance using return on firm-level assets and return on equity.

\section{Data Sources and Summary Statistics}

To make statistically meaningful inferences regarding the performance effects of active asset and portfolio management, we examine data from the three largest property share markets: the USA, the UK, and Australia. These countries have different institutional infrastructures regarding public property companies, including different regulations relating to the discretion management has in the use of free cash flows. In Australia, our sample consists of publicly traded Property Trusts (PTs), which are required to distribute $100 \%$ of accounting earnings in the form of dividends to shareholders in exchange for the non-taxation of income at the PT level. In the UK, listed property companies are subject to the same regulations as other public corporations; in particular, there are no regulatory restrictions regarding the distribution or reinvestment of free cash flows. Moreover, income net of allowable deductions at the entity level is subject to taxation.

In the U.S., our sample includes both publicly traded Real Estate Investment Trusts (REITs) and Real Estate Operating Companies (REOCs). REITs are required to distribute at least $90 \%$ of taxable income as dividends to avoid taxation at the entity level; thus, they are constrained with respect to their use of free cash flow. ${ }^{12}$ REOCs operate as standard "C" corporations and are therefore subject to taxation at the entity level.

Tax-exempt Property Trusts in Australia are allowed to develop properties only for their own portfolio, and may not sell such properties for a number of years. Taxpaying property companies in the UK and REOCs in USA do not operate under such disposition limitations. In addition, no effective limitation of investment property sales has been in place for US REITs since 1997. However, during 1996 and 1997

\footnotetext{
12 Prior to 2001, U.S. REITS were required to distribute $95 \%$ of taxable income to maintain their REIT status.
} 
(the first 2 years of our sample) excess property dispositions could have resulted in the loss of a company's REIT status. ${ }^{13}$

In principle, we could estimate our first stage excess return models using monthly data over shorter (for example, one-year) time periods instead of the 4-year windows we employ. These "1-year" alphas could then be regressed on one-year measures of TRADING, TURNOVER, and EXPANSION (along with other control variables). However, annual versions of our trading intensity proxies are likely to be noisy; that is, not clearly able to distinguish active firms from more passive firms. At the other extreme, estimating the model for the full 1996-2003 sample period may induce significantly more survivorship bias because the number of listed property companies in the three sample countries is known to have grown substantially during these 8 years. To estimate our second stage cross sectional regressions, only companies in existence for the entire 1996-2003 sample period could be included in the analysis. This would limit the dataset to just 28 companies. To both minimize the sample selectivity bias that would be associated with the longer time intervals and avoid the noisy estimates of our intensity measures that would be associated with shorter time periods, we estimate the model using two 4-year subperiods: 1996-1999 and 2000-2003. ${ }^{14}$

Our sampling procedure for Australia and the UK begins with firms in the Global Real Estate Securities Database of Global Property Research (GPR), a Netherlandsbased firm. This database contains prices, stock market capitalizations, dividends, and other company characteristics of real estate companies listed on the stock exchanges of more than 26 countries on a monthly basis since 1984. This unique database contains the history of some 400 real estate companies - both currently listed companies and those that have been delisted. Each country's GPR General Index is constructed to be representative of movements in the country's real estate securities market. ${ }^{15}$ In the USA, we begin our sample selection efforts with the SNL Datasource produced by SNL Financial. ${ }^{16}$ Our three measures of portfolio management intensity have been constructed from annual report information in the U.K. and Australia. In the U.S., these indicators are constructed from data obtained from the SNL DataSource.

From the universe of property companies covered by GPR or SNL in each country, we selected for further analysis those companies for which all of the

\footnotetext{
${ }^{13}$ A REIT must pay a confiscatory $100 \%$ excise tax on profits earned from the sale of property deemed by the Internal Revenue Service to have been held, not as a long-term investment, but rather with the intent to sell for a short-term profit (i.e., "dealer property"). An example of dealer property is acquiring an apartment complex with the intent to convert the units to condominiums. In addition, prior to 1998 a company lost its REIT status if in any year at least $30 \%$ of its gross income was derived from sales of dealer property or real estate held for less than 4 years (even if not dealer property). However, the Real Estate Investment Trust Simplification Act of 1997 ("REITSA") repealed the 30\% gross income test for REITs, while leaving the $100 \%$ excise tax on sales of dealer property largely intact.

14 To minimize survivorship bias, we consider all available property companies with sufficient portfolio data at the beginning of the first sub-period, and follow these companies through that period. This process starts again at the beginning of the second sub-period.

${ }^{15}$ Additional information on GPR and its products can be found at http://www.propertyshares.com/ algemeen/home/index.asp.

${ }^{16}$ More information on SNL's real estate data can be found at http://www.snl.com/real_estate/. 
required data are available for at least one of our two 4-year subperiods. This sampling procedure produced the final set of companies summarized in Table 1. During the 1996-1999 subperiod, the sample includes 41 US companies. The number of Australian and British companies available during this first subperiod is not sufficient for our analysis.

During the 2000-2003 subperiod, our sample includes 146 US companies, 21 Australian firms, and 19 UK companies. The third column of Table 1 provides average 2003 stock market capitalizations in US dollars. Interestingly, these average capitalizations display little variation across countries, ranging from $\$ 1.36$ million in Australia to $\$ 1.43$ million in both the USA and UK. The typical use of leverage, however, differs considerably more across the three countries, with the USA having the highest 2003 average debt-to-asset ratio at 51.9\%. At 7.1 and $6.2 \%$, respectively, dividend yields in Australia and the USA are significantly higher than the $3.4 \%$ average of their UK counterparts. This difference reflects the dividend distribution requirements in the USA and Australia.

Stock return performance statistics are presented in Table 2. From our monthly data, we report annualized mean total returns and standard deviations for our sample firms. For comparison, we also report the corresponding return statistics for the GPR General Index and the Morgan Stanley Capital International (MSCI) All Share Index for each country. The MSCI All Share Index is a broad-based measure of stock return performance in each country.

In the USA, the risk and return characteristics of our sample firms differ little from the broad-based measure of public real estate performance captured by the GPR General Index. Annualized total returns averaged $12.3 \%$ over the entire 1996-2003 sample period. However, US real estate returns varied greatly across the two subperiods, averaging 5 to $6 \%$ in 1996-1999 versus approximately $19 \%$ during the 2000-2003 subperiod. In the UK, our sample firms generated higher average returns over the 2000-2003 sample period than UK's GPR General Index (19.8 vs $15.9 \%$ ), with somewhat less volatility. In contrast, our Australian sample produced somewhat lower average returns than the GPR General Index for Australia during 2000-2003, with slightly less volatility. A noteworthy feature of Table 2 is the extent to which listed property companies outperformed the broader stock market in all three counties over the 2000-2003 subperiod. For example, our US sample produced an average total return of $19.5 \%$; the corresponding return on

Table 1 Sample statistics

\begin{tabular}{lccllll}
\hline Country & Number of companies & $\begin{array}{l}\text { Average Mkt. } \\
\text { capitalization (USD) }\end{array}$ & & Debt-to-assets (\%) & Dividend yield \\
\cline { 2 - 3 } \cline { 5 - 6 } & $1996-1999$ & $2000-2003$ & & 2003 & 2003 & 2003 \\
\hline USA & 41 & 146 & & $\$ 1.43 \mathrm{~B}$ & 51.9 & 6.2 \\
Australia & 4 & 21 & $\$ 1.36 \mathrm{~B}$ & 28.7 & 7.1 \\
UK & 0 & 19 & $\$ 1.43 \mathrm{~B}$ & 40.7 & 3.4 \\
\hline
\end{tabular}

Debt-to-asset ratios are based on the book values of debt and assets. Dividend yields are calculated by dividing 2003 total dividends by 2002 year-end stock prices 
Table 2 Annualized stock return performance statistics

\begin{tabular}{|c|c|c|c|c|c|c|c|}
\hline & & \multicolumn{3}{|c|}{ Mean total return $(\%)$} & \multicolumn{3}{|c|}{ Standard deviation $(\%)$} \\
\hline & & $96-03$ & $96-99$ & $00-03$ & $96-03$ & $96-99$ & $00-03$ \\
\hline \multirow[t]{3}{*}{ US } & Sample & 12.3 & 6.0 & 19.5 & 12.4 & 11.2 & 13.1 \\
\hline & GPR General Index & 12.2 & 5.3 & 19.3 & 12.4 & 13.0 & 11.7 \\
\hline & MSCI All Share Index & 8.9 & 26.6 & -5.1 & 17.3 & 14.9 & 12.3 \\
\hline \multirow[t]{3}{*}{ UK } & Sample & & & 19.8 & & & 14.8 \\
\hline & GPR General Index & & & 15.9 & & & 17.5 \\
\hline & MSCI All Share Index & & & -1.1 & & & 16.2 \\
\hline \multirow[t]{3}{*}{ Australia } & Sample & & & 18.7 & & & 15.8 \\
\hline & GPR General Index & & & 21.6 & & & 16.2 \\
\hline & MSCI All Share Index & & & 10.4 & & & $11.8 \%$ \\
\hline
\end{tabular}

Returns and standard deviations are based on monthly returns and calculated in US dollars. Each country's GPR General Index is produced by Global Properties Research (http:/www.propertyshares.com/algemeen/ home/index.asp) and is constructed to be representative of the movements in the country's real estate securities market. The MSCI All Share Index, produced by Morgan Stanley, is a broad-based measure of stock return performance in each country

the MSCI All Share index for the USA was $-5.1 \%$. In contrast, our US sample of firms significantly underperformed relative to the broader stock market during the 1996-1999 subperiod.

Summary statistics for our composite measure of trading activity, TRADING ${ }_{i}$, are reported in the top panel of Table 3. As previously discussed, TRADING $i$ is calculated by summing the number of acquired and disposed properties and dividing by the average number of properties in the portfolio during the year. Trading activity in the U.S. was relatively high in 1996-1998, with the mean of TRADING ${ }_{i}$ ranging from 0.35 to 0.44 . From 1999 through 2003, however, the average value of TRADING $_{i}$ for US firms fell more than half, ranging from 0.13 to 0.16 . In our Australian sample, TRADING ${ }_{i}$ ranged in average value from 0.15 to 0.31 during 2000-2003. U.K. property companies have been the most active with $\mathrm{TRADING}_{i}$ averaging close to 0.30 throughout the 2000-2003 subperiod.

Our second measure of portfolio management intensity, TURNOVER $i$, captures the dollar value of dispositions rather than the number of property sales. The values reported in the middle panel of Table 3 suggest that portfolio turnover, when measured in dollar values, is mainly concentrated among the larger property companies, especially those listed in Australia and the USA.

Our final measure of portfolio management intensity, EXPANSION $i$, captures the average annual percentage growth in the number of properties in the company's portfolio. In contrast to TRADING $i$ and TURNOVER $i$, EXPANSION $_{i}$ can, and does, take on negative values. As can be seen in the bottom panel of Table 3, the mean value of EXPANSION ${ }_{i}$ for our UK sample ranged from 5 to $8 \%$ during the 2000 2003 subperiod. Similar to the USA, this modest growth was generated by the larger firms. Portfolio growth in our Australian firms during 2000-2003 has greatly exceeded that of the USA and UK, ranging from 12 to $30 \%$. Once again, this significant growth in the average number of properties has been driven exclusively by larger firms.

In short, our three portfolio management intensity indicators suggest that the property companies in the sample have been actively trading and expanding their Springer 
Table 3 Summary statistics for three measures of trading intensity

\begin{tabular}{|c|c|c|c|c|c|c|c|c|}
\hline & 1996 & 1997 & 1998 & 1999 & 2000 & 2001 & 2002 & 2003 \\
\hline \multicolumn{9}{|l|}{ Trading ratios } \\
\hline US mean & 0.35 & 0.44 & 0.36 & 0.16 & 0.16 & 0.15 & 0.13 & 0.15 \\
\hline 25th percentile & 0.07 & 0.12 & 0.12 & 0.05 & 0.03 & 0.02 & 0.03 & 0.04 \\
\hline 75th percentile & 0.48 & 0.61 & 0.49 & 0.21 & 0.18 & 0.15 & 0.19 & 0.17 \\
\hline Australia mean & & & & & 0.22 & 0.31 & 0.15 & 0.27 \\
\hline 25th percentile & & & & & 0.06 & 0.10 & 0.05 & 0.06 \\
\hline 75th mean & & & & & 0.32 & 0.27 & 0.32 & 0.28 \\
\hline 25th percentile & & & & & 0.14 & 0.15 & 0.10 & 0.13 \\
\hline 75th percentile & & & & & 0.36 & 0.29 & 0.44 & 0.40 \\
\hline \multicolumn{9}{|l|}{ Turnover ratios } \\
\hline USA & 0.05 & 0.05 & 0.03 & 0.06 & 0.09 & 0.08 & 0.06 & 0.08 \\
\hline 25th percentile & 0.00 & 0.00 & 0.00 & 0.00 & 0.01 & 0.00 & 0.01 & 0.01 \\
\hline 75th percentile & 0.06 & 0.03 & 0.02 & 0.07 & 0.11 & 0.08 & 0.10 & 0.09 \\
\hline Australia & & & & & 0.04 & 0.04 & 0.03 & 0.04 \\
\hline 25 th percentile & & & & & 0.00 & 0.00 & 0.00 & 0.00 \\
\hline 75 th percentile & & & & & 0.07 & 0.08 & 0.06 & 0.07 \\
\hline UK & & & & & 0.16 & 0.13 & 0.16 & 0.09 \\
\hline 25 th percentile & & & & & 0.07 & 0.08 & 0.05 & 0.05 \\
\hline 75th percentile & & & & & 0.18 & 0.17 & 0.21 & 0.12 \\
\hline \multicolumn{9}{|l|}{ Expansion ratios } \\
\hline USA & 0.37 & 0.60 & 0.48 & 0.18 & 0.05 & 0.05 & 0.03 & 0.04 \\
\hline 25 th percentile & 0.04 & 0.14 & 0.10 & 0.00 & -0.03 & -0.03 & -0.03 & -0.04 \\
\hline 75th percentile & 0.50 & 0.71 & 0.49 & 0.19 & 0.07 & 0.06 & 0.04 & 0.06 \\
\hline Australia & & & & & 0.12 & 0.30 & 0.11 & 0.25 \\
\hline 25 th percentile & & & & & -0.01 & 0.00 & 0.00 & 0.00 \\
\hline 75th percentile & & & & & 0.21 & 0.32 & 0.19 & 0.30 \\
\hline UK & & & & & 0.08 & 0.08 & 0.05 & 0.05 \\
\hline 25th percentile & & & & & -0.06 & -0.03 & -0.08 & 0.04 \\
\hline 75th percentile & & & & & 0.13 & 0.12 & 0.11 & 0.12 \\
\hline
\end{tabular}

This table presents numerical information regarding portfolio size and trading activity of listed property companies. The analysis is based on a common sample comparison for the periods 1996-1999 and 20002003. TRADING ${ }_{i}$ captures the number of properties purchased in a given year, plus the number of properties sold, relative to the average number of properties in the portfolio during the year. TURNOVER is equal to dollar value of sales during time period $t$ divided by the average dollar value of the portfolio or firm in period $t$. The expansion ratio, EXPANSION ${ }_{i}$ captures the average annual increase in the number of properties owned by the firm

portfolios, but that there has been substantial variation across firms, making it possible to distinguish among different portfolio management approaches in the subsequent analysis. In addition, our sample firms display persistent behaviour with respect to trading intensity. For example, firms with an average TRADING ratio exceeding the sample average would be classified as above average in $74 \%$ of all annual cases. This implies that our classification of firms is not driven by our research design or choice of subperiods.

To get a first impression regarding the relationships among our variables, and to check for possible multicollinearity across the explanatory variables in our second stage regressions, we report in Table 4 correlations among our multifactor alphas, measures of trading intensity, and control variables. The correlation coefficients are 
Table 4 Correlation of performance, control variables and activity ratios

\begin{tabular}{lrrrrrrrrr}
\hline & Size & DR & DY & EPS & PER & PtB & TrR & TuR & ExR \\
\hline Debt ratio & -0.06 & & & & & & & & \\
Dividend yield & -0.15 & -0.03 & & & & & & & \\
Earnings per share & 0.08 & -0.22 & 0.20 & & & & & & \\
Price-earnings ratio & 0.03 & -0.02 & -0.15 & -0.03 & & & & & \\
Price-to-book ratio & 0.04 & -0.16 & -0.09 & 0.01 & 0.04 & & & & \\
TRADING & -0.24 & 0.06 & -0.21 & -0.22 & 0.02 & 0.04 & & & \\
TURNOVER & -0.13 & 0.06 & -0.25 & -0.26 & 0.00 & 0.03 & $\mathbf{0 . 7 6}$ & & \\
EXPANSION & -0.16 & 0.04 & 0.03 & 0.04 & 0.07 & 0.03 & $\mathbf{0 . 3 7}$ & -0.18 & \\
Alpha (multifactor) & -0.12 & -0.02 & -0.20 & 0.38 & 0.00 & -0.04 & 0.20 & -0.03 & 0.24 \\
\hline
\end{tabular}

Correlations are cross sectional for the period 2000-2003. Numbers in bold are significant at the 5\% level. TRADING $_{i}$ captures the number of properties purchased in a given year, plus the number of properties sold, relative to the average number of properties in the portfolio during the year. TURNOVER ${ }_{i}$ is equal to dollar value of sales during time period $t$ divided by the average dollar value of the portfolio or firm in period $t$. The expansion ratio, EXPANSION $i$ captures the average annual increase in the number of properties owned by the firm

generally statistically insignificant. However, with a correlation coefficient of 0.76 , TRADING $_{i}$ and TURNOVER $_{i}$ are highly correlated, as expected. The correlation between TRADING $_{i}$ and $\operatorname{EXPANSION}_{i}(\rho=0.37)$ is also positive and significant, whereas the correlation between TURNOVER ${ }_{i}$ and $\operatorname{EXPANSION}_{i}(\rho=-0.18)$ is negative but not statistically significant. The statistically significant correlations among our management intensity indicators causes us to investigate their performance impact separately in our subsequent analysis.

\section{Risk-Adjusted Stock Returns and Operating Performance}

Before regressing excess stock returns on indicators of management intensity, we first examine the association among our intensity indicators and firm performance using several univariate relations. In Table 5, we report the mean values of several performance measures for two clusters of firms. The first cluster contains firms ranked in the top 25th percentile based on trading activity as measured by TRADING $_{i}$. The second cluster contains firms ranked in the bottom 25th percentile.

During 1996-1999, the most active US firms produced an average annual return on assets of $3.7 \%$. The corresponding ROA for the least active firms was a comparable $3.4 \%$. However, the most active US firms produced a significantly higher average return on equity than the least active firms ( $7.3 \mathrm{vs} 0.4 \%$ ), as well as a much higher total stock return. The mean Jensen's alpha, based on monthly data, for our 41 US companies was 0 , with a standard deviation of 0.01 . Our three-factor specification of excess return performance also produced a mean alpha of 0 and a standard deviation of 0.01 . On a risk-adjusted basis, as captured by the single-factor and multifactor alphas, active firms also outperformed their less active counterparts. Based on these univariate statistics, the level of trading activity appears to be positively associated with performance. 
Table 5 Comparison of performance of most and least active firms based on trading

\begin{tabular}{|c|c|c|c|c|c|c|c|c|}
\hline & \multicolumn{4}{|c|}{ 1996-1999 } & \multicolumn{4}{|c|}{$2000-2003$} \\
\hline & $\begin{array}{l}\text { Top, } \\
25 \%\end{array}$ & $\begin{array}{l}\text { Bottom, } \\
25 \%\end{array}$ & Mean & St. dev. & $\begin{array}{l}\text { Top, } \\
25 \%\end{array}$ & $\begin{array}{l}\text { Bottom, } \\
25 \%\end{array}$ & Mean & St. dev. \\
\hline \multicolumn{9}{|l|}{ USA } \\
\hline Return on assets & $3.7 \%$ & $3.4 \%$ & $3.2 \%$ & $1.9 \%$ & $1.3 \%$ & $2.1 \%$ & $2.1 \%$ & $3.3 \%$ \\
\hline Return on equity & $7.3 \%$ & $0.4 \%$ & $5.2 \%$ & $14.0 \%$ & $3.4 \%$ & $-5.2 \%$ & $13.5 \%$ & $160.6 \%$ \\
\hline Total stock return & $14.1 \%$ & $3.4 \%$ & $5.9 \%$ & $13.8 \%$ & $16.2 \%$ & $20.3 \%$ & $19.5 \%$ & $15.3 \%$ \\
\hline $\begin{array}{l}\text { Single-factor } \\
\text { alpha }\end{array}$ & 0.00 & -0.01 & 0.00 & 0.01 & 0.02 & 0.02 & 0.02 & 0.07 \\
\hline Multifactor alpha & 0.01 & -0.01 & 0.00 & 0.01 & 0.01 & 0.01 & 0.01 & 0.03 \\
\hline \multicolumn{9}{|l|}{ Australia } \\
\hline Return on assets & & & & & $6.2 \%$ & $6.2 \%$ & $6.3 \%$ & $0.8 \%$ \\
\hline Return on equity & & & & & $8.7 \%$ & $8.9 \%$ & $9.0 \%$ & $1.1 \%$ \\
\hline Total stock return & & & & & $22.8 \%$ & $15.2 \%$ & $18.7 \%$ & $5.2 \%$ \\
\hline $\begin{array}{l}\text { Single-factor } \\
\text { alpha }\end{array}$ & & & & & 0.01 & 0.00 & 0.01 & 0.01 \\
\hline Multifactor alpha & & & & & 0.01 & 0.00 & 0.01 & 0.01 \\
\hline \multicolumn{9}{|l|}{ UK } \\
\hline Return on assets & & & & & $0.1 \%$ & $0.1 \%$ & $0.1 \%$ & $0.1 \%$ \\
\hline Return on equity & & & & & $4.9 \%$ & $4.1 \%$ & $4.9 \%$ & $2.3 \%$ \\
\hline Total stock return & & & & & $16.6 \%$ & $18.3 \%$ & $19.8 \%$ & $5.8 \%$ \\
\hline $\begin{array}{l}\text { Single-factor } \\
\text { alpha }\end{array}$ & & & & & 0.01 & 0.01 & 0.02 & 0.00 \\
\hline Multifactor alpha & & & & & 0.01 & 0.01 & 0.02 & 0.01 \\
\hline
\end{tabular}

This table provides univariate performance statistics for property companies clustered on the basis of the TRADING ratio. TRADING $i$ is constructed from annual report information in the UK and Australia. In the USA, it is constructed from data obtained from the SNL DataSource (http://www.snl.com/real_estate). Included are average annualized returns and alphas for the top and bottom quartiles, as well as the means and standard deviations of these performance indicators for the periods 1996-1999 and 2000-2003. Total stock returns in each country are proxied for by the Global Property Research (GPR) General Index. The Fama-French multifactor Alphas are obtained from estimating Eq. 4 using monthly data. The single-factor (Jensen's) alphas are obtained from estimating Eq. 4 without the SMB and HML risk factors

The positive relation between trading activity and performance is less apparent, however, in the 2000-2003 subperiod. In the US sample, more active firms did produce, on average, a higher return on equity (3.4 vs $-5.2 \%)$. However, active firms produced both a lower return on assets and lower total stock market return than did less active firms. During the 2000-2003 subperiod, the mean Jensen's alpha for our 143 US companies was 0.02, with a standard deviation of 0.07. Our Fama-French multifactor return specification produced an average Jensen's alpha of 0.01 with a standard deviation of 0.03 . In short, no significant difference between the performance of the most active and least active firms is detectable in the US single-factor or multifactor alphas.

The 2000-2003 univariate results for Australia and UK firms reported in Table 5 are also inconclusive. More active UK firms produced a marginally higher average return on equity than did less active firms. The mean Jensen's alpha and standard deviation estimated for our 14 UK firms during the 2000-2003 subperiod were 0.02 and 0.00 , respectively. The multifactor excess return specification produced very similar results. Moreover, there is no discernable difference in UK risk-adjusted return performance between the top quartile and bottom quartile firms. 
The most active Australian firms did not provide improved operational performance in 2000-2003. However, active firms did produce higher average total returns as well as higher risk-adjusted returns. Average excess return performance, measured with Jensen's alpha, during 2000-2003 for our 20 Australian firms was 0.01 , very similar to our US result. However, the standard deviation of 0.01 indicates less cross-firm variation in excess return performance than observed in our US sample. $^{17}$

\section{Regression Analyses of Management Intensity}

\section{Excess Stock Returns}

Table 6 contains our second stage regression results for US firms using our multifactor alphas as the dependent variable. Results are reported for both the 1996-1999 and 2000-2003 subperiods. The first model reported for each time period contains the results of regressing firm-level alphas on our set of control variables: firm size, debt ratio, dividend yield, earnings per share, price-earnings ratio, and the price-to-book ratio. In Models II, III, and IV, respectively, TRADING ${ }_{i}$, TURNOVER ${ }_{i}$, and EXPANSION $_{i}$ are added with replacement to the set of control variables.

During the 1996-1999 subperiod, the estimated coefficient on Debt Ratio is consistently negative and statistically significant, suggesting that higher leverage decreases risk-adjusted returns in our U.S. sample, all else equal. None of the other control variables are statistically significant. The estimated coefficients on TRADING $_{i}$ (Model II), TURNOVER (Model III), and EXPANSION $_{i}$ (Model IV), although positive, can not be distinguished from zero. The adjusted $R^{2}$ ranges from 0.09 to 0.17 across the four model specifications.

The US results for 2000-2003 are markedly different. First, the estimated coefficients on debt ratio are no longer distinguishable from zero. Second, the estimated coefficients on firm size are uniformly negative and marginally significant, as are the coefficients on dividend yield. Moreover, the coefficients on earnings per share are now positive and highly significant. The addition of TRADING T $_{i}$ (Model II) produces a positive and statistically significant coefficient, as does the separate

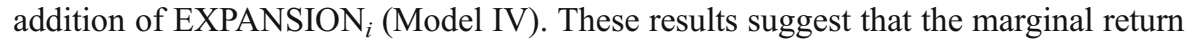
impact of management intensity on risk-adjusted returns is positive. However, the coefficient on TURNOVER (Model III) cannot be distinguished from zero. The adjusted $R^{2}$ for the four model specifications are considerably higher than the 19961999 period, ranging from 0.22 to $0.27 .^{18}$

Table 7 contains the corresponding regression results for our Australian and UK firms during the 2000-2003 subperiod. In Australia, no control variable is

\footnotetext{
${ }^{17}$ During 1996-1999, the Fama-French multifactor model explains $15 \%$ of the variation in our U.S. sample. During 2000-2003, the adjusted $\mathrm{R}^{2}$ declines to $5 \%$. With an adjusted $\mathrm{R}^{2}$ of $19 \%$, the three-factor model explains a much larger \%age of return variation in the U.K. The adjusted $\mathrm{R}^{2}$ of the three-factor model using Australian data is $35 \%$. In the U.S., the correlation between our single and multifactor firm level alphas is 0.95 . The corresponding correlations for the U.K. and Australia are 0.70 and 0.93 , respectively.

${ }^{18}$ We tested a separate model for the U.S. including a dummy for Real Estate Operating Companies. This dummy was not statistically significant, probably due to lack of observations.
} 
Table 6 Cross-sectional regressions of excess stock returns

\begin{tabular}{|c|c|c|c|c|c|c|c|c|}
\hline \multirow[t]{2}{*}{ United States } & \multicolumn{4}{|c|}{ 1996-1999 } & \multicolumn{4}{|c|}{$2000-2003$} \\
\hline & I & II & III & IV & I & II & III & IV \\
\hline Intercept & $\begin{array}{l}0.020 \\
(1.66)\end{array}$ & $\begin{array}{l}0.013 \\
(1.06)\end{array}$ & $\begin{array}{l}0.016 \\
(1.35)\end{array}$ & $\begin{array}{l}0.016 \\
(1.28)\end{array}$ & $\begin{array}{c}0.008 \\
(1.78)\end{array}$ & $\begin{array}{c}0.003 \\
(0.71)\end{array}$ & $\begin{array}{l}0.007 \\
(1.60)\end{array}$ & $\begin{array}{l}0.008 \\
(1.89)\end{array}$ \\
\hline Size & $\begin{array}{l}0.001 \\
(0.57)\end{array}$ & $\begin{array}{l}0.001 \\
(0.03)\end{array}$ & $\begin{array}{l}0.001 \\
(0.30)\end{array}$ & $\begin{array}{l}0.001 \\
(0.15)\end{array}$ & $\begin{array}{l}-0.001 \\
(-2.25)\end{array}$ & $\begin{array}{l}-0.001 \\
(-1.90)\end{array}$ & $\begin{array}{l}-0.001 \\
(-2.25)\end{array}$ & $\begin{array}{l}-0.001 \\
(-2.32)\end{array}$ \\
\hline Debt ratio & $\begin{array}{l}-0.052 \\
(-2.55)\end{array}$ & $\begin{array}{l}-0.047 \\
(-2.43)\end{array}$ & $\begin{array}{l}-0.052 \\
(-2.66)\end{array}$ & $\begin{array}{l}-0.049 \\
(-2.44)\end{array}$ & $\begin{array}{l}0.004 \\
(0.62)\end{array}$ & $\begin{array}{l}0.004 \\
(0.59)\end{array}$ & $\begin{array}{c}0.004 \\
(0.61)\end{array}$ & $\begin{array}{c}0.003 \\
(0.50)\end{array}$ \\
\hline Dividend yield & $\begin{array}{l}0.001 \\
(0.03)\end{array}$ & $\begin{array}{l}0.001 \\
(0.06)\end{array}$ & $\begin{array}{l}0.001 \\
(0.09)\end{array}$ & $\begin{array}{l}0.001 \\
(0.14)\end{array}$ & $\begin{array}{l}-0.001 \\
(-2.38)\end{array}$ & $\begin{array}{l}-0.001 \\
(-1.88)\end{array}$ & $\begin{array}{l}-0.001 \\
(-2.28)\end{array}$ & $\begin{array}{l}-0.001 \\
(-2.56)\end{array}$ \\
\hline Earnings per share & $\begin{array}{c}0.002 \\
(0.46)\end{array}$ & $\begin{array}{c}0.002 \\
(0.58)\end{array}$ & $\begin{array}{l}0.003 \\
(0.81)\end{array}$ & $\begin{array}{l}0.002 \\
(0.14)\end{array}$ & $\begin{array}{l}0.006 \\
(6.51)\end{array}$ & $\begin{array}{l}0.007 \\
(7.08)\end{array}$ & $\begin{array}{l}0.006 \\
(6.41)\end{array}$ & $\begin{array}{l}0.006 \\
(6.34)\end{array}$ \\
\hline Price-earnings ratio & $\begin{array}{l}-0.001 \\
(-0.02)\end{array}$ & $\begin{array}{l}-0.001 \\
(-0.09)\end{array}$ & $\begin{array}{l}-0.001 \\
(-0.32)\end{array}$ & $\begin{array}{l}0.001 \\
(0.13)\end{array}$ & $\begin{array}{l}-0.001 \\
(-0.04)\end{array}$ & $\begin{array}{l}-0.001 \\
(-0.03)\end{array}$ & $\begin{array}{l}-0.001 \\
(-0.03)\end{array}$ & $\begin{array}{l}-0.001) \\
(-0.29)\end{array}$ \\
\hline Price-to-book ratio & $\begin{array}{l}0.000 \\
(1.02)\end{array}$ & $\begin{array}{l}0.000 \\
(1.22)\end{array}$ & $\begin{array}{l}0.001 \\
(1.22)\end{array}$ & $\begin{array}{l}0.001 \\
(1.10)\end{array}$ & $\begin{array}{l}-0.001 \\
(-0.53)\end{array}$ & $\begin{array}{l}-0.000 \\
(-0.66)\end{array}$ & $\begin{array}{l}-0.001 \\
(-0.54)\end{array}$ & $\begin{array}{l}-0.001 \\
(-0.66)\end{array}$ \\
\hline TRADING & & $\begin{array}{l}0.020 \\
(1.83)\end{array}$ & & & & $\begin{array}{c}(0.020) \\
(3.11)\end{array}$ & & \\
\hline TURNOVER & & & $\begin{array}{l}0.066 \\
(1.67)\end{array}$ & & & & $\begin{array}{l}0.003 \\
(0.30)\end{array}$ & \\
\hline EXPANSION & & & & $\begin{array}{l}0.009 \\
(0.98)\end{array}$ & & & & $\begin{array}{l}0.017 \\
(2.97)\end{array}$ \\
\hline$N$ & 34 & 34 & 34 & 34 & 135 & 135 & 135 & 135 \\
\hline $\operatorname{Prob}(F$-stat $)$ & 0.19 & 0.10 & 0.12 & 0.22 & 0.00 & 0.00 & 0.00 & 0.00 \\
\hline$R^{2}$ adjusted & 0.09 & 0.17 & 0.15 & 0.09 & 0.23 & 0.27 & 0.22 & 0.27 \\
\hline
\end{tabular}

Fama-French multivariate alphas, obtained from estimating Eq. 4, is the dependent variable in all specifications. Size is computed as the total book value of assets. The Debt Ratio is total debt divided by total assets, Dividend yield is the sample average of annual dividends divided by prices at the beginning of the year. Earnings per Share is defined as total earnings divided by the number of shares outstanding, the Price-Earnings Ratio is the ratio of the share price and the earnings per share, and the Price-to-book Ratio is the ratio of the company's share price and book value. TRADING captures the number of properties purchased in a given year, plus the number of properties sold, relative to the average number of properties in the portfolio during the year. TURNOVER is equal to dollar value of sales during time period $t$ divided by the average dollar value of the portfolio or firm in period $t$. The expansion ratio, EXPANSION captures the average annual increase in the number of properties owned by the firm over the $n$ year sample period

statistically significant in any of the four specifications. Moreover, the estimated coefficients on TRADING , TURNOVER $_{i}$, and EXPANSION $i$ are all statistically insignificant. The adjusted $R^{2}$ ranges from 0.08 to 0.25 . In the UK, the estimated coefficients on the firm's debt ratio are positive and statistically significant in three of the four model specifications. None of the other control variables have statistically significant coefficients. More importantly, the estimated coefficients on TRADING ${ }_{i}$, TURNOVER $_{i}$, and EXPANSION $i$ statistically insignificant. In short, no association between management intensity and return performance can be discerned from Table 7. Although not reported, we also searched for nonlinear effects by squaring our intensity indicators and adding them to the regressions. None of the estimated coefficients on the squared terms were statistically significant, although their addition did eliminate the statistical significance of the coefficients on $\mathrm{TRADING}_{i}$ and EXPANSION ${ }_{i}$ in our 20002003 US sample. 
Table 7 Cross-sectional regressions of excess stock returns

\begin{tabular}{|c|c|c|c|c|c|c|c|c|}
\hline & \multicolumn{4}{|c|}{ Australia (2000-2003) } & \multicolumn{4}{|c|}{ UK (2000-2003) } \\
\hline & I & II & III & IV & I & II & III & IV \\
\hline Intercept & $\begin{array}{l}-0.023 \\
(-0.57)\end{array}$ & $\begin{array}{l}-0.023 \\
(-0.53)\end{array}$ & $\begin{array}{l}-0.014 \\
(-0.36)\end{array}$ & $\begin{array}{l}-0.029 \\
(-0.66)\end{array}$ & $\begin{array}{l}-0.027 \\
(-1.59)\end{array}$ & $\begin{array}{l}-0.026 \\
(-1.46)\end{array}$ & $\begin{array}{l}-0.025 \\
(-1.40)\end{array}$ & $\begin{array}{l}-0.022 \\
(-1.24)\end{array}$ \\
\hline Size & $\begin{array}{l}-0.001 \\
(-0.89)\end{array}$ & $\begin{array}{l}-0.001 \\
(-0.81)\end{array}$ & $\begin{array}{l}-0.001 \\
(-0.80)\end{array}$ & $\begin{array}{l}-0.001 \\
(-0.88)\end{array}$ & $\begin{array}{c}-0.001 \\
(1.30)\end{array}$ & $\begin{array}{c}-0.001 \\
(0.92)\end{array}$ & $\begin{array}{l}-0.001 \\
(-1.11)\end{array}$ & $\begin{array}{c}-0.001 \\
(1.47)\end{array}$ \\
\hline Debt ratio & $\begin{array}{l}-0.010 \\
(-1.83)\end{array}$ & $\begin{array}{l}-0.098 \\
(-1.73)\end{array}$ & $\begin{array}{l}-0.100 \\
(-1.87)\end{array}$ & $\begin{array}{l}-0.105 \\
(-1.85)\end{array}$ & $\begin{array}{l}0.060 \\
(3.06)\end{array}$ & $\begin{array}{l}0.055 \\
(2.53)\end{array}$ & $\begin{array}{l}0.055 \\
(2.31)\end{array}$ & $\begin{array}{l}0.041 \\
(1.28)\end{array}$ \\
\hline Dividend yield & $\begin{array}{l}0.006 \\
(1.82)\end{array}$ & $\begin{array}{l}0.006 \\
(1.58)\end{array}$ & $\begin{array}{l}0.004 \\
(0.93)\end{array}$ & $\begin{array}{l}0.007 \\
(1.85)\end{array}$ & $\begin{array}{l}0.002 \\
(1.63)\end{array}$ & $\begin{array}{c}0.002 \\
(1.38)\end{array}$ & $\begin{array}{l}0.002 \\
(1.35)\end{array}$ & $\begin{array}{l}0.002 \\
(1.34)\end{array}$ \\
\hline $\begin{array}{l}\text { Earnings per } \\
\text { share }\end{array}$ & $\begin{array}{l}0.144 \\
(1.29)\end{array}$ & $\begin{array}{l}0.135 \\
(1.14)\end{array}$ & $\begin{array}{l}0.060 \\
(0.52)\end{array}$ & $\begin{array}{l}0.144 \\
(1.26)\end{array}$ & $\begin{array}{l}-0.009 \\
(-1.33)\end{array}$ & $\begin{array}{l}-0.007 \\
(-0.93)\end{array}$ & $\begin{array}{l}-0.007 \\
(-0.96)\end{array}$ & $\begin{array}{l}-0.008 \\
(-1.24)\end{array}$ \\
\hline $\begin{array}{l}\text { Price-earnings } \\
\text { ratio }\end{array}$ & $\begin{array}{l}0.001 \\
(0.68)\end{array}$ & $\begin{array}{l}0.000 \\
(0.39)\end{array}$ & $\begin{array}{l}0.001 \\
(0.12)\end{array}$ & $\begin{array}{l}0.001 \\
(0.83)\end{array}$ & $\begin{array}{l}0.001 \\
(1.16)\end{array}$ & $\begin{array}{l}0.001 \\
(1.21)\end{array}$ & $\begin{array}{l}0.001 \\
(1.15)\end{array}$ & $\begin{array}{l}0.001 \\
(0.93)\end{array}$ \\
\hline $\begin{array}{l}\text { Price-to-book } \\
\text { ratio }\end{array}$ & $\begin{array}{l}-0.013 \\
(-0.37)\end{array}$ & $\begin{array}{l}-0.001 \\
(-0.27)\end{array}$ & $\begin{array}{l}0.007 \\
(0.22)\end{array}$ & $\begin{array}{l}-0.012 \\
(-0.33)\end{array}$ & $\begin{array}{l}0.012 \\
(0.96)\end{array}$ & $\begin{array}{l}0.015 \\
(1.04)\end{array}$ & $\begin{array}{l}0.015 \\
(0.99)\end{array}$ & $\begin{array}{l}0.017 \\
(1.15)\end{array}$ \\
\hline TRADING & & $\begin{array}{l}0.007 \\
(0.37)\end{array}$ & & & & $\begin{array}{l}-0.008 \\
(-0.53)\end{array}$ & & \\
\hline TURNOVER & & & $\begin{array}{l}0.093 \\
(1.63)\end{array}$ & & & & $\begin{array}{l}-0.012 \\
(-0.42)\end{array}$ & \\
\hline EXPANSION & & & & $\begin{array}{l}-0.008 \\
(-0.54)\end{array}$ & & & & $\begin{array}{l}0.019 \\
(0.77)\end{array}$ \\
\hline$N$ & 19 & 19 & 19 & 19 & 14 & 14 & 14 & 14 \\
\hline Prob $(F$-stat $)$ & 0.26 & 0.37 & 0.18 & 0.36 & 0.19 & 0.29 & 0.30 & 0.26 \\
\hline$R^{2}$ adjusted & 0.14 & 0.08 & 0.25 & 0.08 & 0.32 & 0.25 & 0.24 & 0.28 \\
\hline
\end{tabular}

Fama-French multivariate alphas, obtained from estimating Eq. 4, is the dependent variable in all specifications. Size is computed as the total book value of assets. The Debt Ratio is total debt divided by total assets, Dividend Yield is the sample average of annual dividends divided by prices at the beginning of the year. Earnings per Share is defined as total earnings divided by the number of shares outstanding, the Price-Earnings Ratio is the ratio of the share price and the earnings per share, and the Price-to-book Ratio is the ratio of the company's share price and book value. TRADING captures the number of properties purchased in a given year, plus the number of properties sold, relative to the average number of properties in the portfolio during the year. TURNOVER is equal to dollar value of sales during time period $t$ divided by the average dollar value of the portfolio or firm in period $t$. The expansion ratio, EXPANSION captures the average annual increase in the number of properties owned by the firm over the $n$ year sample period

Our analysis thus far has not taken property type (a proxy for investment style) into account. This is not a problem if the property type in which a firm specializes is unrelated to return performance or portfolio trading activities. However, returns often vary significantly across the various property types. Moreover, the degree of management required and the returns to scale also may vary across property types. To control for the property type focus of our sample firms, we also run our multivariate regressions with property type dummies as additional control variables. Due to sample size limitations, we could add property focus control variables only to our analysis of US firms in the 2000-2003 subperiod. The diversified property category, the category most represented in our sample, serves as the omitted property type.

The regression results for this extended model specification are provided in Table 8. Adding property focus control variables as a group provides a significant increase in our ability to explain cross-sectional variation in the excess returns of US 
Table 8 Cross-sectional regression of alphas with property type controls

\begin{tabular}{|c|c|c|c|c|}
\hline \multirow[t]{2}{*}{ United States } & \multicolumn{4}{|c|}{ 2000-2003 } \\
\hline & I & II & III & IV \\
\hline Intercept & $\begin{array}{l}0.014 \\
(3.08)\end{array}$ & $\begin{array}{l}0.011 \\
(2.17)\end{array}$ & $\begin{array}{l}0.016 \\
(3.23)\end{array}$ & $\begin{array}{l}0.014 \\
(3.10)\end{array}$ \\
\hline Office-dummy & $\begin{array}{l}-0.003 \\
(-0.94)\end{array}$ & $\begin{array}{l}-0.003 \\
(-0.83)\end{array}$ & $\begin{array}{l}-0.003 \\
(-0.92)\end{array}$ & $\begin{array}{l}-0.003 \\
(-0.85)\end{array}$ \\
\hline Retail-dummy & $\begin{array}{l}0.003 \\
(0.94)\end{array}$ & $\begin{array}{l}0.002 \\
(0.80)\end{array}$ & $\begin{array}{l}0.003 \\
(0.90)\end{array}$ & $\begin{array}{l}0.002 \\
(0.60)\end{array}$ \\
\hline Residential-dummy & $\begin{array}{l}-0.003 \\
(-0.90)\end{array}$ & $\begin{array}{l}-0.003 \\
(-0.82)\end{array}$ & $\begin{array}{l}-0.003 \\
(-0.92)\end{array}$ & $\begin{array}{l}-0.002 \\
(-0.79)\end{array}$ \\
\hline Industrial-dummy & $\begin{array}{l}0.001 \\
(0.20)\end{array}$ & $\begin{array}{l}0.001 \\
(0.33)\end{array}$ & $\begin{array}{l}0.001 \\
(0.10)\end{array}$ & $\begin{array}{l}0.003 \\
(0.06)\end{array}$ \\
\hline Hotel-dummy & $\begin{array}{l}-0.013 \\
(-3.98)\end{array}$ & $\begin{array}{l}-0.013 \\
(-3.34)\end{array}$ & $\begin{array}{l}-0.015 \\
(-4.09)\end{array}$ & $\begin{array}{l}-0.013 \\
(-3.84)\end{array}$ \\
\hline Other-dummy & $\begin{array}{l}0.003 \\
(0.70)\end{array}$ & $\begin{array}{l}0.003 \\
(0.89)\end{array}$ & $\begin{array}{l}0.002 \\
(0.50)\end{array}$ & $\begin{array}{l}0.002 \\
(0.65)\end{array}$ \\
\hline Size & $\begin{array}{l}-0.001 \\
(-1.47)\end{array}$ & $\begin{array}{l}-0.001 \\
(-1.38)\end{array}$ & $\begin{array}{l}-0.001 \\
(-1.53)\end{array}$ & $\begin{array}{l}-0.001 \\
(-1.56)\end{array}$ \\
\hline Debt ratio & $\begin{array}{l}0.001 \\
(0.13)\end{array}$ & $\begin{array}{c}0.001 \\
(0.16)\end{array}$ & $\begin{array}{l}0.001 \\
(0.09)\end{array}$ & $\begin{array}{l}0.001 \\
(0.02)\end{array}$ \\
\hline Dividend yield & $\begin{array}{l}-0.001 \\
(-3.28)\end{array}$ & $\begin{array}{l}-0.001 \\
(-2.97)\end{array}$ & $\begin{array}{l}-0.001 \\
(-3.42)\end{array}$ & $\begin{array}{l}-0.001 \\
(-3.31)\end{array}$ \\
\hline Earnings per share & $\begin{array}{l}0.004 \\
(4.76)\end{array}$ & $\begin{array}{l}0.005 \\
(4.92)\end{array}$ & $\begin{array}{l}0.005 \\
(4.11)\end{array}$ & $\begin{array}{l}0.004 \\
(4.72)\end{array}$ \\
\hline Price-earnings ratio & $\begin{array}{l}-0.001 \\
(-0.42)\end{array}$ & $\begin{array}{l}-0.001 \\
(-0.40)\end{array}$ & $\begin{array}{l}-0.001 \\
(-0.46)\end{array}$ & $\begin{array}{l}-0.001 \\
(-0.56)\end{array}$ \\
\hline Price-to-book ratio & $\begin{array}{l}-0.001 \\
(-0.96)\end{array}$ & $\begin{array}{l}-0.001 \\
(-0.96)\end{array}$ & $\begin{array}{l}-0.001 \\
(-0.96)\end{array}$ & $\begin{array}{l}-0.001 \\
(-1.01)\end{array}$ \\
\hline TRADING & & $\begin{array}{l}0.008 \\
(1.23)\end{array}$ & & \\
\hline TURNOVER & & & $\begin{array}{l}0.008 \\
(1.08)\end{array}$ & \\
\hline EXPANSION & & & & $\begin{array}{l}0.010 \\
(1.68)\end{array}$ \\
\hline$N$ & 135 & 135 & 135 & 135 \\
\hline Prob ( $F$-stat $)$ & 0.00 & 0.00 & 0.00 & 0.00 \\
\hline$R^{2}$ adjusted & 0.37 & 0.37 & 0.37 & 0.38 \\
\hline
\end{tabular}

The omitted property type dummy is the 'diversified' category. Fama-French multivariate alphas are the dependent variable in all specifications. Size is the total book value of assets. The Debt Ratio is total debt divided by total assets, Dividend Yield is the average of annual dividends divided by prices at the beginning of the year. Earnings per Share is total earnings divided by the number of shares outstanding, Price-Earnings Ratio is the share price divided by earnings per share, and Price-to-book Ratio is the ratio of the company's share price and book value. TRADING is the number of properties purchased in a given year, plus the number of properties sold, relative to the average number of properties in the portfolio during the year. TURNOVER is equal to the dollar value of sales divided by the average dollar value of the portfolio in period $t$. EXPANSION captures the average annual increase in the number of properties owned by the firm over the $n$ year sample period

companies. Nevertheless, the only significant property type variable is the hotel dummy, which is negative. Moreover, with the addition of property type control variables, the estimated coefficients on $\mathrm{TRADING}_{i}$ and EXPANSION ${ }_{i}$ are no longer statistically significant. 
Table 9 Multivariate regression analysis of three-factor beta

\begin{tabular}{|c|c|c|c|c|c|c|c|c|}
\hline \multirow[t]{2}{*}{ United States } & \multicolumn{4}{|c|}{ 1996-1999 } & \multicolumn{4}{|c|}{$2000-2003$} \\
\hline & I & II & III & IV & I & II & III & IV \\
\hline Intercept & $\begin{array}{l}1.057 \\
(3.55)\end{array}$ & $\begin{array}{l}1.107 \\
(3.44)\end{array}$ & $\begin{array}{l}1.155 \\
(3.87)\end{array}$ & $\begin{array}{l}0.960 \\
(3.08)\end{array}$ & $\begin{array}{l}0.666 \\
(4.59)\end{array}$ & $\begin{array}{l}0.743 \\
(4.85)\end{array}$ & $\begin{array}{l}0.621 \\
(4.04)\end{array}$ & $\begin{array}{l}0.657 \\
(4.66)\end{array}$ \\
\hline Size & $\begin{array}{c}0.001 \\
(1.77)\end{array}$ & $\begin{array}{c}0.001 \\
(1.81)\end{array}$ & $\begin{array}{l}0.001 \\
(2.11)\end{array}$ & $\begin{array}{l}0.001 \\
(1.24)\end{array}$ & $\begin{array}{l}0.001 \\
(1.15)\end{array}$ & $\begin{array}{l}0.001 \\
(0.94)\end{array}$ & $\begin{array}{l}0.001 \\
(1.24)\end{array}$ & $\begin{array}{l}0.001 \\
(1.18)\end{array}$ \\
\hline Debt ratio & $\begin{array}{l}-0.224 \\
(-0.46)\end{array}$ & $\begin{array}{l}-0.269 \\
(-0.53)\end{array}$ & $\begin{array}{l}-0.234 \\
(-0.49)\end{array}$ & $\begin{array}{l}-0.175 \\
(-0.35)\end{array}$ & $\begin{array}{l}-0.339 \\
(-1.61)\end{array}$ & $\begin{array}{l}-0.331 \\
(-1.58)\end{array}$ & $\begin{array}{l}-0.340 \\
(-1.60)\end{array}$ & $\begin{array}{l}-0.308 \\
(-1.51)\end{array}$ \\
\hline Dividend yield & $\begin{array}{l}-0.064 \\
(-2.59)\end{array}$ & $\begin{array}{l}-0.067 \\
(-2.61)\end{array}$ & $\begin{array}{l}-0.069 \\
(-2.81)\end{array}$ & $\begin{array}{l}-0.062 \\
(-2.46)\end{array}$ & $\begin{array}{l}-0.036 \\
(-3.46)\end{array}$ & $\begin{array}{l}-0.039 \\
(-3.67)\end{array}$ & $\begin{array}{l}-0.034 \\
(-3.15)\end{array}$ & $\begin{array}{l}-0.035 \\
(-3.44)\end{array}$ \\
\hline Earnings per share & $\begin{array}{l}-0.004 \\
(-0.05)\end{array}$ & $\begin{array}{l}0.004 \\
(0.04)\end{array}$ & $\begin{array}{l}-0.019 \\
(-0.20)\end{array}$ & $\begin{array}{l}-0.007 \\
(-0.07)\end{array}$ & $\begin{array}{l}-0.095 \\
(-2.95)\end{array}$ & $\begin{array}{l}-0.087 \\
(-3.13)\end{array}$ & $\begin{array}{l}-0.084 \\
(-2.72)\end{array}$ & $\begin{array}{l}-0.084 \\
(-2.68)\end{array}$ \\
\hline Price-earnings ratio & $\begin{array}{l}-0.002 \\
(-0.71)\end{array}$ & $\begin{array}{l}-0.002 \\
(-0.74)\end{array}$ & $\begin{array}{l}-0.001 \\
(-0.53)\end{array}$ & $\begin{array}{l}-0.001 \\
(-0.54)\end{array}$ & $\begin{array}{l}-0.001 \\
(-1.14)\end{array}$ & $\begin{array}{l}-0.001 \\
(-1.15)\end{array}$ & $\begin{array}{l}-0.001 \\
(-1.07)\end{array}$ & $\begin{array}{l}-0.001 \\
(-0.92)\end{array}$ \\
\hline Price-to-book ratio & $\begin{array}{l}-0.007 \\
(-0.77)\end{array}$ & $\begin{array}{l}-0.008 \\
(-0.78)\end{array}$ & $\begin{array}{l}-0.009 \\
(-0.93)\end{array}$ & $\begin{array}{l}-0.006 \\
(-0.67)\end{array}$ & $\begin{array}{l}-0.001 \\
(-1.23)\end{array}$ & $\begin{array}{l}-0.007 \\
(-1.18)\end{array}$ & $\begin{array}{l}-0.006 \\
(-1.24)\end{array}$ & $\begin{array}{l}-0.006 \\
(-1.15)\end{array}$ \\
\hline TRADING & & $\begin{array}{l}-0.121 \\
(-0.43)\end{array}$ & & & & $\begin{array}{l}-0.343 \\
(-1.53)\end{array}$ & & \\
\hline TURNOVER & & & $\begin{array}{l}-1.546 \\
(-1.58)\end{array}$ & & & & $\begin{array}{l}0.291 \\
(0.88)\end{array}$ & \\
\hline EXPANSION & & & & $\begin{array}{c}0.22 \\
(1.03)\end{array}$ & & & & $\begin{array}{l}-0.603 \\
(-3.02)\end{array}$ \\
\hline$N$ & 34 & 34 & 34 & 34 & 135 & 135 & 135 & 135 \\
\hline Prob ( $F$-stat $)$ & 0.04 & 0.08 & 0.03 & 0.06 & 0.00 & 0.00 & 0.00 & 0.00 \\
\hline$R^{2}$ adjusted & 0.21 & 0.20 & 0.26 & 0.21 & 0.15 & 0.16 & 0.15 & 0.20 \\
\hline
\end{tabular}

The market beta is the dependent variable. Size is computed as the total book value of assets. The Debt Ratio is total debt divided by total assets, Dividend Yield is the sample average of annual dividends divided by prices at the beginning of the year. Earnings per Share is defined as total earnings divided by the number of shares outstanding, the Price-Earnings Ratio is the ratio of the share price and the earnings per share, and the Price-to-book Ratio is the ratio of the company's share price and book value. TRADING captures the number of properties purchased in a given year, plus the number of properties sold, relative to the average number of properties in the portfolio during the year. TURNOVER is equal to dollar value of sales during time period $t$ divided by the average dollar value of the portfolio or firm in period $t$. The expansion ratio, EXPANSION captures the average annual increase in the number of properties owned by the firm over the $n$ year sample period

In summary, these results suggest it is difficult to explain firm-level variations in return performance on the basis of portfolio management intensity. Using multivariate regression specifications that do not control for property type, we find a statistically significant result only for TRADING TR $_{i}$ aXPANSION $i$, and that only for US property companies in the 2000-2003 subperiod. For the Australian and the UK firms in our sample, our management intensity indicators are not significantly related to excess return performance. Furthermore, when we add property type as a control variable to the model specifications, the statistical significance of TRADING $i$ and EXPANSION For $_{i}$ the US sample disappears, suggesting it was the U.S. firms' property type focus and not the intensity of portfolio management that was the main driver of positive excess returns in the 2000-2003 subperiod. ${ }^{19}$ Taken as a whole, these results are not consistent with

\footnotetext{
${ }^{19}$ We have also considered a quadratic relationship between trading intensity and performance, in order to investigate a possible optimum in trading intensity. This analysis did not yield statistically significant results.
} 
Kallberg et al (2000), who find that actively managed REIT mutual funds have higher alphas than passively managed funds.

\section{Trading Intensity and Systematic Risk}

Portfolio managers who can predict, and thereby avoid, downturns in local property markets will produce higher risk-adjusted returns for their clients. Moreover, successful market timing will also decrease the portfolio's covariance with the market. In the remainder of this section, we investigate whether active trading strategies are indeed associated with lower systematic risk.

Table 9 contains our regression results for US firms using our estimated firm-level betas $\left(\beta_{i, \mathrm{MKT}}\right)$ from Eq. 4 as the dependent variable. Results are reported for both the 1996-1999 and 2000-2003 subperiods. During both subperiods, the estimated coefficient on dividend yield is consistently negative and statistically significant,

Table 10 Multivariate regression analysis of three-factor betas

\begin{tabular}{|c|c|c|c|c|c|c|c|c|}
\hline & \multicolumn{4}{|c|}{ Australia (2000-2003) } & \multicolumn{4}{|c|}{ UK (2000-2003) } \\
\hline & I & II & III & IV & I & II & III & IV \\
\hline \multirow[t]{2}{*}{ Intercept } & 1.199 & 1.209 & 1.189 & 1.267 & -0.549 & -0.649 & -0.741 & -0.395 \\
\hline & $(2.61)$ & $(2.53)$ & $(2.45)$ & $(2.61)$ & $(-0.46)$ & $(-0.56)$ & $(-0.61)$ & $(-0.30)$ \\
\hline \multirow[t]{2}{*}{ Size } & -0.001 & -0.001 & -0.001 & -0.001 & 0.001 & 0.001 & 0.001 & 0.001 \\
\hline & $(-1.24)$ & $(-1.14)$ & $(-1.19)$ & $(-1.18)$ & $(0.75)$ & $(1.18)$ & $(0.91)$ & $(0.79)$ \\
\hline \multirow[t]{2}{*}{ Debt ratio } & 0.156 & 0.174 & 0.152 & 0.228 & 1.442 & 2.036 & 2.152 & 0.756 \\
\hline & $(0.26)$ & $(0.27)$ & $(0.64)$ & $(0.36)$ & $(1.05)$ & $(1.43)$ & $(1.35)$ & $(0.32)$ \\
\hline \multirow[t]{2}{*}{ Dividend yield } & -0.033 & -0.037 & -0.029 & -0.040 & 0.035 & 0.059 & 0.059 & 0.026 \\
\hline & $(-0.83)$ & $(-0.43)$ & $(-0.63)$ & $(-0.95)$ & $(0.39)$ & $(0.66)$ & $(0.63)$ & $(0.26)$ \\
\hline \multirow[t]{2}{*}{ Earnings per share } & 0.733 & 0.629 & 0.826 & 0.728 & -0.054 & -0.289 & -0.253 & -0.042 \\
\hline & $(0.59)$ & $(0.48)$ & $(0.57)$ & $(0.57)$ & $(-0.12)$ & $(-0.60)$ & $(-0.50)$ & $(-0.09)$ \\
\hline \multirow[t]{2}{*}{ Price-earnings ratio } & 0.002 & 0.001 & 0.003 & 0.001 & 0.023 & 0.016 & 0.020 & 0.021 \\
\hline & $(0.27)$ & $(0.05)$ & $(0.29)$ & $(0.02)$ & $(1.30)$ & $(0.89)$ & $(1.12)$ & $(1.11)$ \\
\hline \multirow[t]{2}{*}{ Price-to-book ratio } & -0.036 & -0.328 & -0.102 & -0.372 & 0.021 & -0.42 & -0.34 & 0.18 \\
\hline & $(-0.93)$ & $(-0.80)$ & $(-0.88)$ & $(-0.94)$ & $(0.02)$ & $(-0.44)$ & $(-0.34)$ & $(0.17)$ \\
\hline \multirow[t]{2}{*}{ TRADING } & & 0.078 & & & & 1.209 & & \\
\hline & & $(0.21)$ & & & & $(1.18)$ & & \\
\hline \multirow[t]{2}{*}{ TURNOVER } & & & -0.102 & & & & 1.832 & \\
\hline & & & $(-0.14)$ & & & & $(0.92)$ & \\
\hline \multirow[t]{2}{*}{ EXPANSION } & & & & 0.099 & & & & 0.719 \\
\hline & & & & $(0.60)$ & & & & $(0.39)$ \\
\hline$N$ & 19 & 19 & 19 & 19 & 14 & 14 & 14 & 14 \\
\hline Prob ( $F$-stat $)$ & 0.84 & 0.90 & 0.91 & 0.87 & 0.70 & 0.63 & 0.70 & 0.81 \\
\hline$R^{2}$ adjusted & 0.03 & 0.04 & 0.04 & 0.04 & 0.02 & 0.03 & 0.03 & 0.02 \\
\hline
\end{tabular}

The market beta is the dependent variable. Size is computed as the total book value of assets, Debt Ratio is the percentage of total debt of total assets, the Dividend Yield is the sample average of annual dividends divided by the end-of year close prices, Earnings per Share is defined as total earnings divided by the number of shares outstanding, the Price-Earnings Ratio is the ratio of the share price and the earnings per share, and the Price-to-book Ratio is the ratio of the company's share price and book value. TRADING captures the number of properties purchased in a given year, plus the number of properties sold, relative to the average number of properties in the portfolio during the year. TURNOVER is equal to dollar value of sales during time period $t$ divided by the average dollar value of the portfolio or firm in period $t$. The expansion ratio, EXPANSION captures the average annual increase in the number of properties owned by the firm over a $n$ year sample period 
suggesting that higher dividend yields decrease systematic market risk, all else equal. None of the estimated coefficients on the other control variables are statistically significant. Similarly, the estimated coefficients on TRADING $_{i}$ and TURNOVER $i$ cannot be distinguished from zero. The coefficient on $\operatorname{EXPANSION}_{i}$, although insignificant in the 1996-1999 subperiod, is negative and significant in the 20002003 subperiod, suggesting an inverse relation between portfolio growth and systematic risk.

Table 11 Cross-sectional regressions of market betas with property type controls

\begin{tabular}{|c|c|c|c|c|}
\hline \multirow[t]{2}{*}{ United States } & \multicolumn{4}{|c|}{$2000-2003$} \\
\hline & $\mathrm{I}$ & II & III & IV \\
\hline Intercept & $\begin{array}{l}0.376 \\
(2.32)\end{array}$ & $\begin{array}{l}0.352 \\
(1.91)\end{array}$ & $\begin{array}{l}0.194 \\
(1.09)\end{array}$ & $\begin{array}{l}0.379 \\
(2.37)\end{array}$ \\
\hline Office-dummy & $\begin{array}{l}0.155 \\
(1.35)\end{array}$ & $\begin{array}{l}0.158 \\
(1.37)\end{array}$ & $\begin{array}{l}0.159 \\
(1.39)\end{array}$ & $\begin{array}{l}0.140 \\
(1.24)\end{array}$ \\
\hline Retail-dummy & $\begin{array}{l}0.061 \\
(0.57)\end{array}$ & $\begin{array}{l}0.057 \\
(0.54)\end{array}$ & $\begin{array}{l}0.069 \\
(0.67)\end{array}$ & $\begin{array}{l}0.109 \\
(1.03)\end{array}$ \\
\hline Residential-dummy & $\begin{array}{l}0.177 \\
(1.62)\end{array}$ & $\begin{array}{l}0.180 \\
(1.61)\end{array}$ & $\begin{array}{l}0.185 \\
(1.69)\end{array}$ & $\begin{array}{l}0.160 \\
(1.47)\end{array}$ \\
\hline Industrial-dummy & $\begin{array}{l}0.102 \\
(0.66)\end{array}$ & $\begin{array}{l}0.107 \\
(0.68)\end{array}$ & $\begin{array}{l}0.136 \\
(0.88)\end{array}$ & $\begin{array}{l}0.132 \\
(0.85)\end{array}$ \\
\hline Hotel-dummy & $\begin{array}{l}0.487 \\
(3.96)\end{array}$ & $\begin{array}{l}0.499 \\
(3.79)\end{array}$ & $\begin{array}{l}0.575 \\
(4.53)\end{array}$ & $\begin{array}{l}0.461 \\
(3.78)\end{array}$ \\
\hline Other-dummy & $\begin{array}{l}0.177 \\
(1.32)\end{array}$ & $\begin{array}{l}0.183 \\
(1.33)\end{array}$ & $\begin{array}{l}0.235 \\
(1.74)\end{array}$ & $\begin{array}{l}0.189 \\
(1.42)\end{array}$ \\
\hline Size & $\begin{array}{c}0.001 \\
(0.44)\end{array}$ & $\begin{array}{c}0.001 \\
(0.46)\end{array}$ & $\begin{array}{c}0.001 \\
(0.59)\end{array}$ & $\begin{array}{l}0.001 \\
(0.55)\end{array}$ \\
\hline Debt ratio & $\begin{array}{l}-0.170 \\
(-0.78)\end{array}$ & $\begin{array}{l}-0.162 \\
(-0.74)\end{array}$ & $\begin{array}{l}-0.117 \\
(-0.54)\end{array}$ & $\begin{array}{l}-0.160 \\
(-0.74)\end{array}$ \\
\hline Dividend yield & $\begin{array}{l}-0.035 \\
(-3.32)\end{array}$ & $\begin{array}{l}-0.035 \\
(-3.17)\end{array}$ & $\begin{array}{l}-0.029 \\
(-2.77)\end{array}$ & $\begin{array}{l}-0.034 \\
(-3.34)\end{array}$ \\
\hline Earnings per share & $\begin{array}{l}-0.043 \\
(-1.30)\end{array}$ & $\begin{array}{l}-0.040 \\
(-1.13)\end{array}$ & $\begin{array}{l}-0.016 \\
(-0.44)\end{array}$ & $\begin{array}{l}-0.040 \\
(-1.21)\end{array}$ \\
\hline Price-earnings ratio & $\begin{array}{l}-0.001 \\
(-0.97)\end{array}$ & $\begin{array}{l}-0.001 \\
(-0.95)\end{array}$ & $\begin{array}{l}-0.001 \\
(-0.87)\end{array}$ & $\begin{array}{l}-0.001 \\
(-0.79)\end{array}$ \\
\hline Price-to-book ratio & $\begin{array}{l}-0.005 \\
(-1.00)\end{array}$ & $\begin{array}{l}-0.005 \\
(-0.99)\end{array}$ & $\begin{array}{l}-0.005 \\
(-0.99)\end{array}$ & $\begin{array}{l}-0.005 \\
(-0.96)\end{array}$ \\
\hline TRADING & & $\begin{array}{l}0.069 \\
(0.28)\end{array}$ & & \\
\hline TURNOVER & & & $\begin{array}{l}0.816 \\
(2.48)\end{array}$ & \\
\hline EXPANSION & & & & $\begin{array}{l}-0.482 \\
(-2.32)\end{array}$ \\
\hline$N$ & 135 & 135 & 135 & 135 \\
\hline Prob ( $F$-stat $)$ & 0.00 & 0.00 & 0.00 & 0.00 \\
\hline$R^{2}$ adjusted & 0.23 & 0.26 & 0.21 & 0.26 \\
\hline
\end{tabular}

Firm-level market betas are the dependent variable. The betas were obtained by fist estimating the multifactor (Fama-French) time series model represented by Eq. 4. The three factor alpha is the dependent variable. Size is computed as the total book value of assets, Debt Ratio is the percentage of total debt of total assets, the Dividend Yield is the sample average of annual dividends divided by the end-of year close prices, Earnings per Share is defined as total earnings divided by the number of shares outstanding, the Price-Earnings Ratio is the ratio of the share price and the earnings per share, and the Price-to-book Ratio is the ratio of the company's share price and book value 
Table 10 contains the corresponding regression results for our Australian and UK firms during the 2000-2003 subperiod. In both Australia and the UK, no control variable is statistically significant in any of the four model specifications. Moreover, the estimated coefficients on TRADING $i$, TURNOVER $_{i}$, and EXPANSION Ere all $_{i}$ statistically insignificant. In short, no association between management intensity and systematic risk can be discerned from Table 10.

When controlling for the property type specialization of our US firms (see Table 11), we find that TURNOVER $i$ is positively associated with the systematic risk of the firm, which suggests that trading activity is pro-cyclical, rather than countercyclical. In contrast, growth in the number of owned properties, as captured by EXPANSION $i$, tends to reduce a firm's systematic risk, all else equal.

Although not separately reported, our property type dummies and other control variables explain $42 \%$ of the variation in ROA in our US sample during the 2000 2003 subperiod. However, the only variable with a statistically significant coefficient is earnings per share $(t$-statistic $=7.92)$. Moreover, when separately added TRADING $_{i}$ and TURNOVER $_{i}$ are strikingly insignificant, although the coefficient on EXPANSION $_{i}$ is positive and significant $(t$-statistic $=2.42)$.

The explanatory power of our ROE regressions is significantly less than the ROA specifications, with $R^{2}$ ranging from 0.06 to 0.07 . Moreover, the coefficient on earning per share is no longer significant and even $\operatorname{EXPANSION}_{i}$ plays no significant role in explaining the cross section of ROE in our US sample.

\section{Summary and Conclusion}

This paper attempts to quantify the value added arising from the active management skills of real estate portfolios by exploring a database of listed property companies in Australia, the UK and the USA. Historically, listed property companies in these three countries were generally not managed in an active fashion. Rather, real estate companies were typically investment vehicles that provided investors access to a liquid and diversified portfolio of properties acquired in private direct real estate markets. In the last decade, however, public real estate firms in all three countries have become more actively managed and focused - either geographically and/or by property type.

We identify four potential sources of manager value added including (1) the ability to improve the risk-return characteristics of the investor's portfolio through portfolio diversification; (2) the ability to pick property type and geographic "winners and losers" and to time the market; (3) deal execution skills; and (4) the efficient provision of ongoing asset and property management services. The important roles played by portfolio diversification and ongoing management in protecting and enhancing risk-adjusted commercial real estate returns are widely acknowledged. However, the extent to which active portfolio managers can add, or destroy, value by pursuing tactical (opportunistic) asset selection and investment timing strategies is not well understood. This paper examines the question: Do real estate portfolio managers who pursue such opportunistic investment strategies add value for investors? 
We define active managers of public real estate firms as those who pursue tactical market timing and asset selection strategies for their private property portfolios. Such opportunistic investment strategies should produce more trading activity than more passive buy-and-hold strategies. Three indicators of portfolio management intensity are developed. We then analyze the relation between our measures of management intensity and performance in two ways. First, we place property companies into quartiles on the basis of portfolio trading activity, and look at a set of performance indicators for the bottom and top quartile. None of these univariate statistics shows a consistent relation between trading activity and risk-adjusted stock return performance.

We next develop multivariate regression models to explain variations in excess stock return performance and systematic risk. In the first stage of the regression analysis, both single-factor and multifactor (i.e. Fama-French) asset pricing models are estimated using monthly firm-level excess returns as the dependent variable. The intercepts (i.e., "alphas") from these time series models are then regressed in a second stage on our measures of portfolio trading intensity. In a second set of crosssectional models, we regress our estimated firm level market betas on our proxies for management intensity. These second stage regressions of alphas and betas also control for variables found in previous studies to be helpful in explaining the crosssection of excess returns and systematic risk. When the property type focus of the firm is included as a control variable, none of our indicators of portfolio management intensity are statistically significant in explaining return performance. Our attempts to explain cross-sectional variation in firm-level systematic risk and operating performance using our measures of management intensity are equally unsuccessful.

Our empirical results suggest it is difficult for mangers of public real estate companies buying properties in private markets to generate outperformance on the basis of the active trading strategies quantified in this paper. This suggests that even if private commercial real estate markets do exhibit the inefficiencies often attributed to them by practitioners, these inefficiencies may not be large enough to compensate investors for the additional trading costs associated with active portfolio management strategies.

Several limitations of our research design are worth noting. First, we cannot observe or proxy for variation across managers in deal execution and on-going property and asset management skills. However, our inability to carefully control for other sources of manager value-added may impede our ability to isolate the effects of trading intensity. Second, "trading intensity" may in fact play a role in the determination of a firm's excess returns and systematic risk. However, the effect may be too small economically when compared to the importance of diversification and the efficient provision of ongoing property and asset management.

Given the importance of, and interest in, the ability of real estate managers to add value through active trading strategies, additional research on this topic is needed. One approach would be to examine alternative proxies for trading intensity than those developed here. In addition, it would be useful to conduct a similar study of private real estate firms/funds if adequate data on returns and trading intensity could be obtained. 
Acknowledgement The authors gratefully acknowledge research support from the Real Estate Research Institute. We thank Jacques Gordon, Martin Hoesli, seminar participants at the University of Geneva and Maastricht University, three anonymous referees, and participants to the 2005 Real Estate Research Institute's annual research symposium. Excellent research assistance was provided by Hugh Marble. Furthermore, Jeroen Beimer is thanked for providing access to the GPR database.

\section{References}

Akerlof, R. (1970). The market for 'Lemons': Quality uncertainty and the market mechanism. Quarterly Journal of Economics, 84, 488-500.

Baker, M., Litov, L., Wachter, J. A., \& Wurgler, J. (2004). Can mutual fund managers pick stocks?. Working Paper, Harvard Business School.

Boer, D., Brounen, D., \& Op 't Veld, H. (2005). Corporate focus and stock performance: Evidence from international real estate markets. Journal of Real Estate Finance and Economics, 31, 200-219.

Brooks, C., \& Tsolacos, S. (2003). International evidence on the predictability of returns to securitized real estate assets: Econometric models versus neural networks. Journal of Property Research, 20, 133-155.

Capozza, D. R., \& Seguin, P. J. (1999). Focus, transparency, and value. Real Estate Economics, 27(1), 587-620.

Carhart, M. (1997). On persistence in mutual fund performance. Journal of Finance, 52, 57-82.

Chen, Y., Ferson, W., \& Peters, H. (2005). The timing ability of fixed income mutual funds. Working Paper, Boston College.

Chen, H. L., Jegadeesh, N., \& Wermers, R. (2001). The value of active mutual fund management: An examination of the stockholdings and trades of fund managers. The Journal of Financial and Quantitative Analysis, 35, 343-368.

Chen, K., Roll, R., \& Ross, S. (1986). Economic forces and the stock market. Journal of Business, 59, 383-403.

Conner, P., \& Liang, Y. (2003). The expanding frontier of institutional real estate. Prudential Real Estate Investors. Retrieved May from http://www.prudential.com/prei.

Cooper, M., Downs, D., \& Patterson, G. (1995). Asymmetric information and the predictability of real estate returns. Journal of Real Estate Finance and Economics, 20, 225-244.

Eichholtz, P. M. A., Koedijk, K., \& Schweitzer, M. (2001). Global property investment and the costs of international diversification. Journal of International Money and Finance, 20, 349-366.

Engstrom, S. (2003). Costly information, diversification, and international mutual fund performance. Pacific-Basin Finance Journal, 11, 463-482.

Fama, E. F. (1970). Efficient capital markets: A review of theory and empirical work. Journal of Finance, $25,383-417$.

Fama, E., \& French, K. (1996). Multifactor explanations of asset pricing anomalies. Journal of Finance, $51(1), 55-83$.

Ferson, W., \& Harvey, C. (1991). The variation of economic risk premiums. Journal of Political Economy, 99, 385-415.

Hall, C. (2004). Six ways to boost your property's value. Wall Street Journal, 2004, April 9.

Han, J. (1996). Targeting markets is popular: A survey of pension real estate investment advisors. Real Estate Finance, Spring, 66-75.

Jensen, C. M. (1968a). The performance of mutual funds in the period 1945-1964. Journal of Finance, 23, 389-416.

Jensen, C. M. (1968b). Risk, the pricing of capital assets, and the evaluation of investment portfolios. Journal of Business, 42, 167-247.

Kallberg, J. G., Liu, C. L., \& Trzcinka, C. (2000). The value added from investment managers: An examination of funds of REITs. Journal of Financial and Quantitative Analysis, 35, 387-408.

Karolyi, G. A., \& Sanders, A. B. (1998). The variation of economic risk premiums in real estate returns. Journal of Real Estate Finance and Economics, 17, 245-262.

Kosowski, R., Timmerman, A., White, H., \& Wermers, R. (2005). Can mutual fund 'Stars' really pick stocks? New evidence from a bootstrap analysis. Working Paper, University of Maryland.

Li, Y., \& Wang, K. (1995). The predictability of REIT returns and market segmentation. Journal of Real Estate Research, 10, 471-482. 
Ling, D. C. (2005). A random walk down main street: Can experts predict returns on commercial real estate? Journal of Real Estate Research, 27(2), 137-155.

Ling, D. C., \& Naranjo, A. (1997). Economic risk factors and commercial real estate returns. Journal of Real Estate Finance and Economics, 13, 283-307.

Ling, D. C., Naranjo, A., \& Ryngaert, M. D. (2000). The predictability of equity REIT returns: Time variation and economic significance. Journal of Real Estate Finance and Economics, 20, 117-136.

Liu, C. H., \& Mei, J. (1992). The predictability of returns on equity REITs and their co-movement with other assets. Journal of Real Estate Finance and Economics, 5, 401-418.

Marcato, G., \& Key, A. (2005). Investment in private real estate: Momentum profits and their robustness to trading costs. Journal of Portfolio Management, 31, 55-69.

McAllister, P., Newell, G., \& Matysiak, G. (2005). An evaluation of the performance of UK real estate forecasters. Working Paper, University of Reading.

Mei, J., \& Liu, C. (1994). The predictability of real estate returns and market timing. Journal of Real Estate Finance and Economics, 8, 115-135.

Sharpe, W. F., Alexander, G. J., \& Bailey, J. V. (1999). Investments, Sixth Edition. Prentice-Hall.

Smith, R. A. (2005). Savvy investors seek properties with 'Hair'. Wall Street Journal, 2005, January 4.

Stoesser, J. W., \& Hess, R. C. (2000). Differentiating higher return strategies in property markets. Prudential Real Estate Investors. Retrieved August from http:/www.prudential.com.

Wermers, R. (2000). Mutual fund performance: An empirical decomposition into stock-picking talent, style, transaction costs, and expenses. Journal of Finance, 55(4), 1655-1695.

Wermers, R. (2003). Are mutual fund shareholders compensated for active management 'Bets'? Working Paper, University of Maryland. 